DOI: $10.19195 / 0137-1134.117 .3$

\author{
KATARZYNA JAWORSKA
}

ORCID: 0000-0003-0018-2775

Uniwersytet Warmińsko-Mazurski w Olsztynie

\title{
ZATRUDNIENIE W SPÓŁDZIELNI SOCJALNEJ
}

\begin{abstract}
Abstrakt: Spółdzielnia socjalna jest dość specyficznym podmiotem funkcjonującym na rynku pracy. Jej podstawowym zadaniem jest reintegracja społeczna i zawodowa jej członków, a nie działalność zarobkowa. Ustawodawca ograniczył krąg osób, które mogą być założycielami, a następnie członkami spółdzielni. Jednocześnie członkowie muszą pozostawać ze spółdzielnią w więzi prawnej. Preferowaną podstawą zatrudnienia jest spółdzielcza umowa o pracę, jednak dopuszczalne jest pod pewnymi warunkami powierzenie pracy na podstawie umowy cywilnoprawnej. Na tym gruncie pojawia się problem faktycznej możliwości realizacji celów spółdzielni socjalnej oraz składu jej organów w zakresie dokonywania czynności z zakresu prawa pracy. Wskazane kwestie skłaniają do podjęcia rozważań nad zatrudnieniem w spółdzielni socjalnej.
\end{abstract}

Słowa kluczowe: zatrudnienie, spółdzielnia socjalna, ekonomia społeczna, prawo pracy, prawo spółdzielcze

\section{WPROWADZENIE}

Spółdzielnia socjalna w polskim porządku prawnym jest stosunkowo młodą instytucją. Pierwszy raz pojawiła się w ustawie z dnia 20 kwietnia 2004 roku o promocji zatrudnienia i instytucjach rynku pracy ${ }^{1}$. Zgodnie z brzmieniem ówczesnego art. 127 tej ustawy spółdzielnia socjalna jako nowy rodzaj spółdzielni pracy została wprowadzona do ustawy z dnia 16 września 1982 roku Prawo spółdzielcze $^{2}$. Przyjęte rozwiązania miały charakter marginalny, nie wskazano także celu i ekonomicznych mechanizmów działania spółdzielni socjalnych. Pewne wskazówki znalazły się w ustawie z dnia 13 czerwca 2003 roku o zatrudnieniu socjalnym $^{3}$. Natomiast pełna regulacja prawa spółdzielni socjalnych została zawarta w ustawie z dnia 27 kwietnia 2006 roku o spółdzielniach socjalnych ${ }^{4}$, która następnie była kilkakrotnie nowelizowana.

1 Tekst jedn. Dz.U. z 2018 r. poz. 1265 ze zm.

2 Tekst jedn. Dz.U. z 2018 r. poz. 1285.

3 Tekst jedn. Dz.U. z 2019 r. poz. 217.

4 Tekst jedn. Dz.U. z 2018 r. poz. 1205. 
Bez wątpienia spółdzielnia socjalna na gruncie polskiego prawodawstwa pełni te same funkcje, które wynikają z europejskiego modelu społecznego. Do podstawowych funkcji przedsiębiorstwa społecznego — spółdzielni socjalnej — zalicza się reintegrację osób z niepełnosprawnością i osób zagrożonych wykluczeniem społecznym oraz pomoc w zaadaptowaniu się na komercyjnym rynku pracy $^{5}$. Ponadto spółdzielnia socjalna $\mathrm{w}$ polskim porządku prawnym wpisuje się w definicję Międzynarodowego Związku Spółdzielni. Zgodnie z tą definicją spółdzielnia socjalna to

podmiot gospodarczo-społeczny powstały jako autonomiczne stowarzyszenie osób dobrowolnie godzących się zaspokoić swoje potrzeby i aspiracje gospodarcze, społeczne i kulturalne. Podmiot ten to wspólne przedsiębiorstwo osób zagrożonych wykluczeniem społecznym, osób o niskiej zatrudnialności umożliwiający aktywizację zawodową oraz przywrócenie im społecznych ról6.

\section{ZAŁOŻYCIELE I CZŁONKOWIE SPÓŁDZIELNI SOCJALNEJ}

Z założenia beneficjantami działalności spółdzielni socjalnej są osoby zagrożone wykluczeniem społecznym ${ }^{7}$. Ustawodawca do tej grupy włączył bezrobotnych $^{8}$, absolwentów centrum integracji społecznej (w rozumieniu art. 2 pkt 1a ustawy z dnia 13 czerwca 2003 roku o zatrudnieniu socjalnym), absolwentów klubu integracji społecznej (art. 2 pkt $1 \mathrm{~b}$ tejże ustawy), osoby z niepełnosprawnością (w rozumieniu art. 4 ustawy z dnia 27 sierpnia 1997 roku o rehabilitacji zawodowej i społecznej oraz zatrudnianiu osób niepełnoprawnych ${ }^{9}$ ), poszukujące zatrudnienia i niezatrudnione osoby do trzydziestego roku życia oraz po ukończeniu pięćdziesiątego roku życia, opiekunowie osoby niepełnosprawnej niepobierający świadczeń socjalnych z tego tytułu, a jednocześnie niepozostający w zatrudnieniu i niewykonujący innej pracy zarobkowej, osoby poszukujące pracy i niepozostające w zatrudnieniu i niewykonujące innej pracy zarobkowej oraz osoby usamodzielniane (w rozumieniu art. 140 ust. 1 i 2 ustawy z dnia 9 czerwca 2011 roku o wspieraniu rodziny i systemie pieczy zastępczej $\left.{ }^{10}\right)$.

Tak ukształtowany krąg beneficjentów działalności spółdzielni socjalnej nie pozostaje bez wpływu na ustawowy cel działalności spółdzielni socjalnej. Prawo-

${ }^{5}$ D. Jarre, Europejski model społeczny i usługi socjalne użyteczności publicznej. Możliwości dla sektora gospodarki społecznej, „Zeszyty Gospodarki Społecznej” 2007, nr 2, s. 63.

${ }^{6}$ Ministerstwo Pracy i Polityki Społecznej, Ocena stanu spółdzielczości socjalnej, Warszawa 2007, s. 2.

7 Zob. R. Szarfenberg, Pojęcie wykluczenia społecznego, [w:] Przeciw wykluczeniu społecznemu, red. M. Duda, B. Gulla, Kraków 2009, s. 6 n.

8 Więcej o definicji bezrobotnego Z. Góral, Prawne pojęcie bezrobotnego, „Studia Prawno-Ekonomiczne" 53, 1996, s. 23 n.; K. Jaworska, Prawna konstrukcja bezrobotnego, [w:] Podmiotowość w prawie, red. B. Sitek, M. Szwejkowska, Olsztyn 2012, s. 47 n.

9 Tekst jedn. Dz.U. z 2018 r. poz. 511 ze zm.

10 Tekst jedn. Dz.U. z 2018 r. poz. 998 ze zm. 
dawca postawił spółdzielniom zasadniczo dwa obligatoryjne cele ${ }^{11}$. Pierwszym z nich jest prowadzenie działań na rzecz społecznej reintegracji członków i pracowników spółdzielni socjalnej, którzy są zagrożeni wykluczeniem społecznym. Powinny być to działania mające na celu odbudowanie i podtrzymanie umiejętności uczestniczenia w życiu społeczności lokalnej i odgrywania ról społecznych w miejscu pracy, zamieszkania lub pobytu. Drugim natomiast jest prowadzenie działań na rzecz zawodowej reintegracji członków spółdzielni oraz pracowników zagrożonych wykluczeniem społecznym. Przy czym celem tych działań ma być odbudowanie i podtrzymanie zdolności do samodzielnego świadczenia pracy na rynku pracy. Jednocześnie ustawodawca zastrzegł, że wszystkie działania o charakterze reintegracyjnym nie mogą być realizowane w ramach prowadzonej przez spółdzielnię działalności gospodarczej. Muszą więc to być działania o innym charakterze, realizowane niezależnie od aktywności zarobkowej.

W związku z tak postawionym celem działalności spółdzielni socjalnych ustawodawca przywiązał też dużą wagę do określenia podmiotów, które mogą założyć taką spółdzielnię, oraz trybu jej tworzenia. Zasadniczo więc na gruncie ustawy o spółdzielniach socjalnych możliwe jest utworzenie spółdzielni albo przez osoby fizyczne, albo osoby prawne. Wśród osób fizycznych przede wszystkim znalazły się wskazane osoby fizyczne zagrożone wykluczeniem społecznym, pod warunkiem że mają pełną zdolność do czynności prawnych. Dopuszczalne jest także utworzenie spółdzielni przez te osoby wraz z osobami, które nie mieszczą się w kategorii zagrożonych wykluczeniem społecznym, pod warunkiem jednak, że nie będą stanowić więcej niż 50\% ogólnej liczby założycieli. Ustawodawca dopuścił też możliwość utworzenia spółdzielni w innej kombinacji osób fizycznych. Jeśli spółdzielnię socjalną zakładają osoby o znacznym lub umiarkowanym stopniu niepełnosprawności, osoby niezagrożone wykluczeniem społecznym mogą stanowić nie więcej niż 70\% ogólnej liczby członków założycieli. Podobnie gdy przedmiotem działalności spółdzielni socjalnej będzie prowadzenie usług pomocy społecznej (w rozumieniu ustawy z dnia 12 marca 2004 roku o pomocy społecz$n^{12}{ }^{12}$, rehabilitacji zawodowej i społecznej osób niepełnosprawnych, opieki nad dziećmi do lat trzech (w rozumieniu ustawy z dnia 4 lutego 2011 roku o opiece nad dziećmi w wieku do lat $3^{13}$ ) lub prowadzenia niepublicznych przedszkoli lub innych form wychowania przedszkolnego. Natomiast w drugiej grupie podmiotów mogących założyć spółdzielnię socjalną znajdują się osoby prawne: organizacje pozarządowe (fundacje, stowarzyszenia), jednostki samorządu terytorialnego i kościelne osoby prawne. W związku tak uregulowaną konstrukcją członków założycieli spółdzielni należy stwierdzić, iż generalną zasadą wyrażaną na gruncie ustawy o spółdzielniach socjalnych jest tworzenie spółdzielni albo przez osoby fi-

11 Por. Z. Niedbała, Zakładanie $i$ wspieranie spółdzielni socjalnych jako działania ograniczające bezrobocie, [w:] Bezrobocie i polityka zatrudnienia, red. Z. Góral, Warszawa 2013, s. 255.

12 Tekst jedn. Dz.U. z 2018 r. poz. 1508 ze zm.

13 Tekst jedn. Dz.U. z 2019 r. poz. 409 ze zm. 
zyczne, albo osoby prawne. Wspólne utworzenie spółdzielni przez osoby fizyczne i osoby prawne nie jest zabronione na mocy ustawy. Skoro więc spółdzielnię socjalną mogą utworzyć trzy osoby fizyczne lub dwie osoby prawne, to można więc przyjąć, iż spółdzielnia może zostać założona przez łącznie osoby fizyczne i osoby prawne, właśnie w takiej konfiguracji. Jednak jest to rozwiązanie niespotykane ${ }^{14}$.

Właściwie dobrane podmioty założycielskie spółdzielni socjalnej nie są jedynym warunkiem niezbędnym do prowadzenia działalności przez spółdzielnię. Spółdzielnia socjalna może działać, tylko jeśli jej skład jest odpowiedni. Zgodnie z ustawą spółdzielnia nie może liczyć mniej niż pięć osób bez względu na to, czy są to osoby fizyczne, czy prawne, i nie więcej niż 50 osób fizycznych. Dolny limit liczby członków związany jest z zapewnieniem prawidłowego funkcjonowania spółdzielni i racjonalnością jej bytu zarówno w zakresie realizacji celów związanych z reintegracją społeczną oraz zawodową, jak i w zakresie ekonomicznym. Górny limit natomiast jest ściśle powiązany z celem funkcjonowania spółdzielni. Ponadto wprowadzenie limitu ma także zapewnić utworzenie i zachowanie więzi między członkami spółdzielni przez bezpośredni kontakt budujący przede wszystkim zaufanie ${ }^{15}$. Wydaje się, że w razie większej niż 50 liczby członków spółdzielni utrzymanie bezpośrednich relacji opartych na zaufaniu byłoby niemożliwe.

Skoro ustawodawca przewidział inną liczbę członków-założycieli spółdzielni i inną liczbę członków spółdzielni niezbędnych do jej zgodnego z prawem funkcjonowania, to nie dziwi, iż obowiązkiem członków-założycieli jest osiągnięcie w ustawowym terminie wymaganej minimalnej liczby członków. Jeżeli spółdzielnię utworzyły trzy osoby fizyczne, to w ciągu roku od dnia zarejestrowania spółdzielni w Krajowym Rejestrze Sądowym mają one obowiązek przyjąć w poczet członków i zatrudnić dwie osoby zagrożone wykluczeniem społecznym. Natomiast jeżeli założycielami spółdzielni są osoby prawe, to warunkiem utrzymania zarejestrowanej spółdzielni jest zatrudnienie, w ciągu sześciu miesięcy od dnia rejestracji w Krajowym Rejestrze Sądowym, co najmniej pięciu osób spośród osób zagrożonych wykluczeniem społecznym. Niespełnienie tego warunku prowadzi z mocy prawa do likwidacji spółdzielni. W związku z tym należy przyjąć, że taka spółdzielnia socjalna została utworzona warunkowo.

\section{WIĘŹ PRAWNA MIĘDZY SPÓŁDZIELNIĄ SOCJALNĄ A JEJ CZŁONKIEM}

Zgodnie z art. 12 ust. 1 ustawy o spółdzielniach socjalnych spółdzielnia ma obowiązek pozostawać w pewnej więzi prawnej ze swoimi członkami. Ustawa jednak nie wprowadza monopolu spółdzielczej umowy o pracę jako podstawy prawnej

14 B. Godlewska-Bujok, C. Mierzejewski, A. Muzyka, Komentarz do ustawy o spółdzielniach socjalnych, Warszawa 2018, s. 35.

15 Ibidem, s. 56. 
wykonywania pracy przez członka spółdzielni. Jest to domyślna forma prawna, choć dopuszczalna jest także umowa o pracę. Tym samym ustawodawca przesądził, iż członek spółdzielni jest pracownikiem, a spółdzielnia socjalna ma status pracodawcy w rozumieniu art. 3 k.p. z wszystkimi tego konsekwencjami. W związku z tym między członkiem spółdzielni a spółdzielnią powstaje stosunek pracy, a więc praca wykonywania przez członka spółdzielni jest pracą podporządkowaną.

Statusu pracownika mogą pozbawić siebie tylko członkowie spółdzielni. Mają oni prawo przewidzieć w statucie, że jej członkowie mogą wykonywać pracę na podstawie umowy o pracę nakładczą, umowy zlecenia lub umowy o dzieło. Tym samym jeżeli żaden ze spółdzielców nie będzie wykonywał pracy w ramach stosunku pracy, spółdzielnia zostanie pozbawiona statusu pracodawcy lub nigdy go nie nabędzie.

Trzeba zauważyć, że odstąpienie na gruncie statutu od zatrudnienia na podstawie spółdzielczej umowy o pracę na rzecz umów cywilnoprawnych nie ma swobodnego charakteru. Ustawodawca zastrzegł, iż może to być uzasadnione tylko rodzajem działalności spółdzielni (art. 201 ust. 1 Prawa spółdzielczego). Ponadto wydaje się, że ograniczeniem tu będą także regulacje prawa pracy. Między pracownikiem a pracodawcą rodzi się szczególna więź w postaci stosunku pracy. W jej ramach pracownik zobowiązuje się do wykonywania pracy określonego rodzaju na rzecz pracodawcy, pod jego kierownictwem oraz w miejscu i czasie przez niego wyznaczonym, a pracodawca do zatrudnienia pracownika za wynagrodzeniem. W konsekwencji zatrudnienie w takich warunkach zawsze będzie stosunkiem pracy bez względu na nazwę zawartej przez strony umowy. Dodatkowo nie bez znaczenia jest także cel spółdzielni socjalnej — doprowadzenie do reintegracji zawodowej i społecznej jej członków. Jednym z istotnych tu zadań jest zapewnienie bezpieczeństwa socjalnego członkom spółdzielni. Bez tego elementu działanie na rzecz odbudowy i podtrzymania zdolności do samodzielnego świadczenia pracy na rynku pracy będzie niemożliwe lub znacznie utrudnione.

Oznacza to, że podstawę zatrudnienia członków spółdzielni determinuje nie tylko rodzaj prowadzonej przez spółdzielnię działalności, lecz także sposób wykonywania pracy, czy ma być ona podporządkowana, czy może być świadczona swobodnie. Wpływ ma sam cel, dla którego została utworzona spółdzielnia socjalna. W związku z tym podstawową formą zatrudnienia członków spółdzielni socjalnej powinna być spółdzielcza umowa o pracę. Przemawia za tym wzmożona ochrona członka spółdzielni socjalnej16. Występuje ona na gruncie ustawy Prawo spółdzielcze w postaci ograniczenia prawa do wypowiedzenia stosunku pracy (art. 186 Prawa spółdzielczego), wręczenia wypowiedzenia zamieniającego (art. 184 Prawa spółdzielczego) oraz wykluczenia z grona członków (art. 24 Prawa spółdzielczego). Członkowi spółdzielni zatrudnionemu na podstawie spółdzielczej umowy o pracę lub umowy o pracę przysługuje także ochrona przewidziana w prawie pracy. Tylko

16 M. Gersdorf, Spółdzielnie socjalne, [w:] Z zagadnień współczesnego prawa pracy. Księga jubileuszowa Profesora Henryka Lewandowskiego, red. Z. Góral, Warszawa 2009, s. 457. 
dla przykładu można wskazać ochronę wynagrodzenia za pracę, przepisy dotyczące czasu pracy, prawo do urlopu wypoczynkowego czy prawo do równego traktowania.

\section{DOKONYWANIE CZYNNOŚCI Z ZAKRESU PRAWA PRACY W SPÓŁDZIELNI SOCJALNEJ}

Pracodawcą jest jednostka organizacyjna, nawet jeżeli nie ma osobowości prawnej, jeżeli zatrudnia pracownika. $Z$ art. $3^{1}$ k.p. wynika, iż za pracodawcę będącego jednostką organizacyjną czynności w sprawach z zakresu prawa pracy dokonuje osoba lub organ zarządzający tą jednostką albo inna wyznaczona do tego osoba. Na tym gruncie koniecznie jest ustalenie podmiotu dokonującego czynności z zakresu prawa pracy w spółdzielni socjalnej.

Obowiązkowymi organami spółdzielni socjalnej są walne zebranie członków oraz zarząd spółdzielni. Nie ma obowiązku powołania rady nadzorczej. Jeśli jej nie ma, zadania rady wykonuje walne zebranie członków spółdzielni.

Skład i liczbę członków zarządu określa statut spółdzielni socjalnej, z zastrzeżeniem, że członkiem zarządu może być tylko osoba fizyczna. $Z$ ustawy o spółdzielniach socjalnych nie wynika jednak, aby były to osoby, które są członkami spółdzielni socjalnej. Mimo to członkowie zarządu wykonują pracę w charakterze pracownika i są zatrudnieni na podstawie umowy o pracę lub spółdzielczej umowy o pracę. Przy czym z członkami zarządu stosunek pracy nawiązuje rada nadzorcza, a jeśli jej nie ma - walne zgromadzenie (art. 12 ust. 1b ustawy o spółdzielniach socjalnych).

Zgodnie z art. 48 § 1 Prawa spółdzielczego do zadań zarządu spółdzielni należy kierowanie działalnością spółdzielni oraz reprezentowanie jej na zewnątrz. Oznacza to, iż domyślnie zarząd spółdzielni dokonuje w imieniu spółdzielni czynności w sprawach z zakresu prawa pracy. Dopuszczalne jest także wyznaczenie przez walne zebranie członków innej osoby, o której mowa w art. $3^{1} \S 1$ in fine k.p. Zaznaczyć jednak trzeba, że nie będą miały zastosowania w tym zakresie przepisy o pełnomocnictwie ${ }^{17}$.

Należy zauważyć, że zgodnie z art. 49 Prawa spółdzielczego dopuszcza się zarząd jednoosobowy. Wówczas nie może dokonywać czynności w sprawach wynikających ze stosunku członkostwa - przyjmowanie nowych członków, wnioskowanie o pozbawienie członkostwa przez wykreślenie czy wykluczenie. Trzeba tu zwrócić uwagę, iż spółdzielcza umowa o pracę nie ma charakteru samodzielnego, jej byt uzależniony jest od bytu stosunku członkostwa ${ }^{18}$. Uwzględniając, że spółdzielnia socjalna ma obowiązek pozostawania w stosunku prawnym ze swoimi członkami, w szczególności na podstawie spółdzielczej umowy o pracę, to czynności ze sfery

17 P. Prusinowski, Reprezentacja pracodawcy w ujęciu podmiotowym, „Przegląd Prawa i Administracji” 113, 2018, s. 97.

18 Ł. Pisarczyk, Spółdzielcza umowa o prace, https://sip-1lex-1pl-10000f4qya39c.han.uwm. edu.pl/\#/publication/469831143 (dostęp: 15.03.2019). 
stosunku członkostwa wpływają bezpośrednio na sferę stosunku pracowniczego. Mimo iż stosunek członkostwa jest powiązany ze stosunkiem pracy powstałym na mocy spółdzielczej umowy o pracę, to jeżeli wykonywanie czynności z zakresu prawa pracy zostało powierzone ,innej wyznaczonej do tego osobie” na podstawie art. $3^{1} \S 1$ in fine k.p., to nie będzie miała ona legitymacji do wykonywania czynności w zakresie stosunku członkowskiego w spółdzielni socjalnej. Konieczne będzie tu pełnomocnictwo udzielone uchwałą przez walne zebranie członków spółdzielni.

Do rady nadzorczej spółdzielni mogą być wybierani wyłącznie członkowie spółdzielni. Jeżeli członkiem spółdzielni jest osoba prawna, do rady może być wybrana osoba niebędąca członkiem spółdzielni, wskazana przez osobę prawną (art. 45 ust. 2 Prawa spółdzielczego). Ale jak już wspomniano, spółdzielnia socjalna nie ma obowiązku tworzenia rady nadzorczej. Jeśli jej nie ma, czynności rady realizuje walne zebranie. Jednak ani ustawa o spółdzielniach socjalnych, ani Prawo spółdzielcze nie wskazują, w jaki sposób walne zebranie dokonuje czynności z zakresu prawa pracy w stosunku do członków zarządu. Regulacja taka powinna więc znaleźć się w statucie spółdzielni socjalnej. Przy czym w wypadku podejmowania decyzji kolegialnie powinna mieć zastosowanie zasada, że głosowania kadrowe są tajne.

Brak obowiązku utworzenia rady nadzorczej w wypadku spółdzielni socjalnej jest jak najbardziej uzasadniony. Zgodnie z art. 45 ust. 1 Prawa spółdzielczego rada nadzorcza składa się z co najmniej trzech osób. Zważywszy, że spółdzielnia socjalna może działać w minimalnym pięcioosobowym składzie, to większość członków spółdzielni zasiadałaby w tym organie. Ponadto z racji pełnionej funkcji członkowie rady spółdzielni podlegają szczególnej ochronie trwałości stosunku pracy tak jak osobie reprezentującej zakładową organizację związkową wobec pracodawcy. Oznacza to, że na podstawie art. 32 ust. 1 ustawy o związkach zawodowych ${ }^{19}$ spółdzielnia socjalna nie może bez zgody rady nadzorczej spółdzielni wypowiedzieć, rozwiązać stosunku pracy ani zmienić jednostronnie warunków pracy lub wynagrodzenia na niekorzyść osobie, która jest członkiem tej rady. Nie oznacza to jednak, że jeśli nie ma rady, a jej funkcje realizuje walne zebranie, taka ochrona trwałości stosunku pracy przysługuje wszystkim członkom walnego zebrania.

\section{WNIOSKI}

Jedną z podstawowych zasad prawa spółdzielczego jest obowiązek pozostawania z członkiem spółdzielni w stosunku pracy. Ze względu na specyfikę spółdzielni preferowana jest spółdzielcza umowa o pracę. Zasada ta nabiera szczególnego znaczenia w wypadku spółdzielni socjalnej, której podstawowym celem jest reintegracja społeczna i zawodowa jej członków. Prowadzenie takich działań nie

19 Ustawa z dnia 20 maja 1991 roku o związkach zawodowych, tekst jedn. Dz.U. z 2019 r. poz. 263. 
jest możliwe bez objęcia członków spółdzielni zagrożonych wykluczeniem społecznym ochroną wynikającą zarówno z prawa spółdzielczego, jak i z prawa pracy.

Na zakończenie warto zaznaczyć, że obowiązek prowadzenia działalności reintegracyjnej w imieniu spółdzielni socjalnej będzie realizować jej zarząd. Realizacja tego obowiązku może być jednak utrudniona, jeżeli w zarządzie i w radzie nadzorczej spółdzielni zasiadają osoby zagrożone wykluczeniem społecznym. W związku z tym trzeba uznać, że wprowadzone w ostatnich latach zmiany do ustawy o spółdzielniach socjalnych w prawidłowy sposób rozszerzyły krąg osób, które mogą być założycielami i członkami spółdzielni, przez dopuszczenie osób niezagrożonych wykluczeniem i osób prawnych.

\section{EMPLOYMENT IN A SOCIAL COOPERATIVE}

\section{Summary}

A social cooperative is a rather specific entity operating on the labour market. Its principal task is the social and professional reintegration of its members rather than gainful activity. The legislator has curtailed the group of people who can be founders and later members of the cooperative. At the same time, members must remain legally bound to the cooperative. The preferred basis for employment is a cooperative contract of employment, but it is permissible to entrust work on the basis of a civil-law contract under certain conditions. This raises the problem of the actual possibility of achieving the objectives of a social cooperative and the composition of its bodies in respect of activities performed under the labour law. The issues indicated above encourage reflection on employment in a social cooperative.

Keywords: employment, social cooperative, social economy, labour law, cooperative law

\section{BIBLIOGRAFIA}

Gersdorf M., Spółdzielnie socjalne, [w:] Z zagadnień współczesnego prawa pracy. Księga jubileuszowa Profesora Henryka Lewandowskiego, red. Z. Góral, Warszawa 2009.

Godlewska-Bujok B., Mierzejewski C., Muzyka A., Komentarz do ustawy o spółdzielniach socjalnych, Warszawa 2018.

Góral Z., Prawne pojęcie bezrobotnego, „Studia Prawno-Ekonomiczne” 53, 1996.

Jarre D., Europejski model spoleczny i usługi socjalne użyteczności publicznej. Możliwości dla sektora gospodarki społecznej, „Zeszyty Gospodarki Społecznej” 2007, nr 2.

Jaworska K., Prawna konstrukcja bezrobotnego, [w:] Podmiotowość w prawie, red. B. Sitek, M. Szwejkowska, Olsztyn 2012.

Niedbała Z., Zakładanie $i$ wspieranie spółdzielni socjalnych jako działania ograniczające bezrobocie, [w:] Bezrobocie i polityka zatrudnienia, red. Z. Góral, Warszawa 2013.

Pisarczyk Ł., Spółdzielcza umowa o pracę, https://sip-1lex-1pl-10000f4qya39c.han.uwm.edu.pl/\#/ publication/469831143 (dostęp: 15.03.2019).

Prusinowski P., Reprezentacja pracodawcy w ujęciu podmiotowym, „Przegląd Prawa i Administracji” 113, 2018.

Szarfenberg R., Pojęcie wykluczenia spolecznego, [w:] Przeciw wykluczeniu społecznemu, red. M. Duda, B. Gulla, Kraków 2009.

Przegląd Prawa i Administracji 117, 2019

(C) for this edition by CNS 